\title{
PARADYGMATY PEDAGOGIKI W OFICJALNYM DYSKURSIE PEDAGOGICZNYM JAKO NARZĘDZIU POLITYKI EDUKACYJNEJ
}

\section{Abstract \\ The pedagogic paradigms in official pedagogical discourse as a device of educational policy}

Nowadays, the quality of our educational policy for students with special needs is unsufficient. The goal of the article is to show possible dependencies between the language used in the contemporary official pedagogical discourse (educational policy tool) and the way in which students with special educational needs are perceived. On the basis of critical analysis of the provisions of selected educational law acts, I will show that these acts are dominated by descriptions which are characteristic for the biological paradigm of disability perception and which could imply negative stereotypes and stigmatization of students with special needs.

Keywords: educational policy, critical analysis of educational law text, pedagogic paradigms

\section{Streszczenie}

W dzisiejszych czasach jakość naszej polityki edukacyjnej wobec uczniów ze specjalnymi potrzebami jest niewystarczająca. Celem artykułu jest ukazanie możliwych zależności pomiędzy językiem, jakim posługuje się współczesny oficjalny dyskurs pedagogiczny (narzędzie polityki edukacyjnej), a sposobem, w jaki są postrzegani uczniowie ze specjalnymi potrzebami edukacyjnymi. Na podstawie przeprowadzonej krytycznej analizy przepisów wybranych aktów prawa oświatowego pokazano, że dominują w nich zapisy charakterystyczne dla paradygmatu biologicznego postrzegania niepełnosprawności, mogące utrwalać negatywne stereotypy i stygmatyzację uczniów ze specjalnymi potrzebami.

Słowa kluczowe: polityka edukacyjna, krytyczna analiza tekstu prawa oświatowego, paradygmaty pedagogiki

Ponad 25 lat temu ustawą z dnia 7 września 1991 roku wszystkim dzieciom i młodzieży (bez względu na stan ich zdrowia i sprawności) przyznano prawo do 
kształcenia się w każdym typie szkoły. Jednak, jak wynika z badań, jakość praktyki edukacyjnej dotyczącej uczniów z tzw. specjalnymi potrzebami (dalej SPE) nie jest zadowalająca. Pomimo ugruntowania się już integracyjnych form kształcenia jako jednych z możliwych form edukacji społeczna pozycja uczniów ze specjalnymi potrzebami edukacyjnymi w klasie pozostaje na niskim poziomie, a sam proces integracji często bywa nazywany integracją pozorowaną, a nawet ukrytą segregacją, wobec której stosunek niektórych nauczycieli można określić jako „maskowany opór” [m.in. Bobeł, 2003: 330-331; Przybylski, 2003: 22-23].

Celem podjętych przeze mnie badań było sprawdzenie i opisanie, czy i w jaki sposób utrwalaniu tej niekorzystnej sytuacji wielu uczniów ze specjalnymi potrzebami edukacyjnymi może sprzyjać język, w jakim sformułowane jest obowiązujące prawo oświatowe. Przyjmując za Jacques'em Lacanem, iż tekst aktu prawnego nie jest tylko zbiorem nakazów i zakazów, ale strukturą obciążoną znaczeniami [Lacan, 1996], założyłam, że silnie utrwalone stereotypy w postrzeganiu uczniów ze SPE, zwłaszcza niepełnosprawnych, niedostosowanych społecznie czy zagrożonych niedostosowaniem społecznym, oprócz społeczno-kulturowych uwarunkowań, mogą być podtrzymywane przez rekontekstualizowanie w kluczowych dla funkcjonowania systemu oświaty podstawach prawnych niektórych pojęć i określeń reprezentatywnych dla ustępującego, biologicznego paradygmatu postrzegania trudności rozwojowych i w uczeniu się.

Za teoretyczną podstawę moich badań przyjęłam koncepcję produkcji, reprodukcji i rekontekstualizacji pedagogicznego dyskursu brytyjskiego pedagoga Basila Bernsteina [2003]. Przedmiotem moich badań stały się bowiem rekontekstualizowane w tekstach wybranych aktów prawa oświatowego językowe określenia dotyczące uczniów ze specjalnymi potrzebami edukacyjnymi (oraz dedykowanych im działań) i ich paradygmatyczna inherencja. Z perspektywy jakościowej i z zastosowaniem metody krytycznej analizy dyskursu w ujęciu Teuna Adrianusa van Dijka [2001] w wybranych aktach prawa oświatowego poszukiwałam przepisów odnoszących się do uczniów ze specjalnymi potrzebami edukacyjnymi, po czym dokonałam ich klasyfikacji ze względu na kryterium językowej „przynależności” do zasobu pojęciowego określonych pedagogicznych paradygmatów. Rezultaty moich badań mogą przyczynić się do lepszego poznania i eliminowania mechanizmów stygmatyzacji społecznej, reprodukowania i używania w codziennym języku zawartych w aktach prawa oświatowego określeń sprzyjających utrwalaniu stereotypów w postrzeganiu osób odbiegających od społecznie i kulturowo przyjętej „,normy”.

Basil Bernstein, wybitny brytyjski socjolog i pedagog, zakładał, iż oficjalny dyskurs pedagogiczny jest narzędziem transmisji makropolityki i kontroli państwa w dziedzinie oświaty [Bernstein, 2000: 33; Martin-Jones, de Mejia, Homberger, 2008: 41-52]. Twierdził, że dyskurs ten tworzony jest w obszarze produkcji (uniwersytety, instytuty badawcze), rekontekstualizowany przez narodowe ministerstwa edukacji m.in. w aktach prawnych dotyczących oświaty, po czym reprodukowany w obszarze m.in. instytucji uczenia się (szkoły, uczelnie itd.) [Bernstein, 2003: 192]. Za pośrednictwem oficjalnego dyskursu pedagogicznego, jak twierdził Bernstein, państwo oferuje różnym kategoriom uczniów dostęp do 
wybranych form wiedzy, wpływając tym samym na tworzenie się ich (różnych) tożsamości [Martin-Jones, de Mejia, Homberger, 2008: 41-52], a także kształtuje społeczną tożsamość i społeczne interakcje między uczniami i nauczycielami [Bernstein, 2003]. W świetle teorii Bernsteina oficjalny dyskurs pedagogiczny staje się zatem narzędziem urządzania uczniów, a rekontekstualizowane w nim znaczenia - swoistym językiem tego urządzania. Warto zatem postawić pytanie o to, jakim językiem w oficjalnym dyskursie pedagogicznym „mówi się” o uczniach ze specjalnymi potrzebami edukacyjnymi, a następnie o to, czy sposób ten przeciwstawia się, czy też raczej sprzyja znanemu z licznych pedagogicznych i socjologicznych doniesień zjawisku stygmatyzacji i stereotypizacji sposobu ich społecznego postrzegania.

Na silną stygmatyzację i utrzymywanie się negatywnych stereotypów postrzegania uczniów z trudnościami w rozwoju i uczeniu się wskazują wyniki licznych badań prezentowane w postaci zarówno naukowych opracowań, jak i raportów z monitoringu publikowanych przez różne organizacje oraz instytucje państwowe, samorządowe i inne (Fundację Rozwoju Dzieci im. J.A. Komeńskiego [Olechowska, 2006], Centrum Metodyczne Pomocy Psychologiczno-Pedagogicznej [Kummant, 2008], Helsińską Fundację Praw Człowieka [Ciechanowski i in., 2010], Najwyższą Izbę Kontroli [2012] i wiele innych). W sięgającej ćwierć wieku tradycji badawczej brano pod uwagę możliwy wpływ wielu różnych czynników determinujących nie w pełni satysfakcjonujący przebieg procesów prointegracyjnych w polskich placówkach oświatowych. Szczególnie dokładnie dotychczas badano w tym zakresie postawy i przygotowanie nauczycieli [Wachowiak, 1992; Gajdzica 2001, 2003, 2011; Jachimczak, 2008; Chrzanowska, 2010; Jankowska, 2012; Buchnat, 2014]. Wśród innych czynników mogących wpływać na kształtowanie się niekorzystnego wizerunku edukacji integracyjnej wskazywano także na niedostosowanie szkół do potrzeb i możliwości uczniów, niezadowalające rezultaty społecznej integracji uczniów pełno- i niepełnosprawnych, silne stereotypy i nawyki w postępowaniu z uczniami mającymi specjalne potrzeby edukacyjne, spóźnioną diagnozę niepełnosprawności czy brak zaspokojenia potrzeb wczesnego wspomagania rozwoju [Chrzanowska, 2010] oraz charakter przyczyn i stopień trudności uczniów stwarzających większe wymagania w porównaniu ze sprawnymi, pomyślnie funkcjonującymi uczniami [m.in. Domagała-Zyśk, 2012].

Choć niezbyt często, to jednak niektórzy badacze, poszukując możliwych czynników determinujących przebieg, jakość czy skuteczność procesu edukacji, podejmowali także próby eksplorowania prawnych podstaw kształcenia uczniów z trudnościami w rozwoju i uczeniu się (z różnie uwarunkowanymi trudnościami w uczeniu się, specjalnymi potrzebami edukacyjnymi). Rozważano zatem m.in. prawa dzieci i młodzieży niepełnosprawnej w ogólnym kontekście praw dziecka [Bińczycka, 2000, 2002, 2005; Czyż, 2002; Dębniak, 2001; Głębowski, 2009; Jachimczak, 2009; Jankowska, 2012; Kamiński, 2006; Kościelska, 2000; Kurowski, 2009, 2010; Mikołajczyk-Lerman, 2012; Ochonczenko, 2005; Przybysz, 1997; Szeroczyńska, 2004; Szymańczak, 1999; Zima, Sałagan, 2008], stan zabezpieczenia i realizację praw społecznych osób niepełnosprawnych [Baron-Wiaterek, 2010; Mikołajczyk-Lerman, 2013; Kawczyńska-Butrym, 2002; Rutkowiak, Krause, 
2009; Perlin, 2002; Warzywoda-Kruszyńska, 2011; Woźniak, 2008], a także prawa dzieci i młodzieży niepełnosprawnych do edukacji oraz przemian, jakie zachodzą w tym zakresie w ostatnich dekadach [Dudzińska, 2009, 2012; Gajdzica, 2007; Kubicki, 2012; Kukla, Duda, Czerw-Bajer, 2011; Maciarz, 1992; Osiecka, 1998; Rzecznik Praw Obywatelskich, 2012a, 2012b, 2013; Sowa, 2006; Szumski, 2006; Warzywoda-Kruszyńska, Holets, 2011; Wiącek, 2008; Zabłocki 1999].

Nie spotkałam natomiast dotychczas opracowania, w którym podjęto by problematykę językowych cech aktów prawa oświatowego. Tymczasem, biorąc pod uwagę, że Ustawa o systemie oświaty oraz liczne rozporządzenia Ministra Edukacji Narodowej stanowiące przynależne jej akty wykonawcze są obowiązkową podstawą podejmowania wszelkich instytucjonalnych działań wobec uczniów, można sądzić, że siła ich społecznego oddziaływania musi być znacząca. Przemawia za nią także autorytet ich twórców, czyli ogólnie rzecz ujmując, samego państwa. Język przepisów prawa dotyczącego uczniów z trudnościami rozwojowymi i edukacyjnymi może zatem sprzyjać uznawaniu prezentowanych w nich określeń za kanon oraz podsuwać „sposób pojmowania zjawisk umożliwiający jej odbiorcom uczestniczenie w dyskursie publicznym" [Jagiełło i in., 2014: 156; por. Dreesen, Judkowiak, 2012]. Zapewne może również stanowić podstawę konstruowania społecznych reprezentacji uczniów z trudnościami rozwojowymi i edukacyjnymi. To wszystko zatem sprawia, że obowiązujące i stosowane w codziennej praktyce prawo oświatowe może być jednym $\mathrm{z}$, istotnych źródeł transmisji dominujących konstrukcji dyskursywnych" [Jagiełło i in., 2014: 156; por. Dreesen, Judkowiak, 2012].

Do badań własnych wybrałam następujące obowiązujące dokumenty z zakresu tzw. prawa oświatowego, w których zawarto przepisy odnoszące się do uczniów z różnie uwarunkowanymi trudnościami rozwojowymi i w uczeniu się w placówkach ogólnodostępnych i integracyjnych (według brzmienia i porządku ich zamieszczenia w dniu 22 maja 2017 roku na stronie internetowej Ośrodka Rozwoju Edukacji [http://www.ore.edu.pl]):

- Ustawę o systemie oświaty z dnia 20 lutego 2015 r. o zmianie ustawy o systemie oświaty oraz niektórych innych ustaw (Dz.U. z 2015 r., poz. 357);

- Ustawę z dnia 14 grudnia 2016 r. Prawo oświatowe (Dz.U. z 2017 r., poz. 59, 949);

- Rozporządzenie Ministra Edukacji Narodowej z dnia 9 sierpnia 2017 r. w sprawie warunków organizowania kształcenia, wychowania i opieki dla dzieci i młodzieży niepełnosprawnych, niedostosowanych społecznie i zagrożonych niedostosowaniem społecznym (Dz.U. z 2017 r., poz. 1578);

- Rozporządzenie Ministra Edukacji Narodowej z dnia 10 czerwca 2015 r. w sprawie szczegółowych warunków i sposobu oceniania, klasyfikowania i promowania uczniów i słuchaczy w szkołach publicznych (Dz.U. z 2015 r., poz. 843);

- Rozporządzenie Ministra Edukacji Narodowej z dnia 30 kwietnia 2013 r. z późn. zm. w sprawie zasad udzielania i organizacji pomocy psychologiczno-pedagogicznej w publicznych przedszkolach, szkołach i placówkach (Dz.U. z 2013 r., poz. 532); 
- Rozporządzenie Ministra Edukacji Narodowej z dnia 1 lutego 2013 r. w sprawie szczegółowych zasad działania publicznych poradni psychologiczno-pedagogicznych, w tym publicznych poradni specjalistycznych (Dz.U. z 2013 r., poz. 199);

- Rozporządzenie Ministra Edukacji Narodowej z dnia 24 sierpnia 2017 r. w sprawie organizowania wczesnego wspomagania rozwoju dzieci (Dz.U. z 2017 r., poz. 1635);

- Rozporządzenie Ministra Edukacji Narodowej z dnia 9 sierpnia 2017 r. $\mathrm{w}$ sprawie indywidualnego obowiązkowego rocznego przygotowania przedszkolnego dzieci i indywidualnego nauczania dzieci i młodzieży (Dz.U. z 2017 r., poz. 1616).

Kluczem do analizy i klasyfikacji określeń językowych zawartych w wybranych aktach prawnych były charakterystyki opisywanych w literaturze pedagogicznych paradygmatów, do których dopasowałam wypisane $\mathrm{z}$ analizowanych aktów prawnych określenia dotyczące uczniów z trudnościami rozwojowymi i edukacyjnymi ${ }^{1}$. Za podstawowe dla prowadzonej przeze mnie analizy przyjęłam dwa przeciwstawne sposoby definiowania i opisywania niepełnosprawności, czyli paradygmat biologiczny i paradygmat humanistyczny [por. m.in. Krause, 2010; Chrzanowska, 2015]. Dychotomiczny podział paradygmatów przyjęłam po to, aby pozwolił on na wyraźne spolaryzowanie stanowisk i odpowiadających im językowych reprezentacji ujawnionych w przepisach prawa oświatowego dotyczących uczniów z trudnościami rozwojowymi edukacyjnymi.

Za charakterystyczne dla biologicznego paradygmatu przyjmuje się postrzeganie niepełnosprawności w przeważającym stopniu jako choroby, braku lub deficytu jednostki, którą po podjęciu autorytarnych decyzji należy poddać diagnozie, leczeniu i rehabilitacji, aby mogła stać się w jak najwyższym stopniu zdolna do przebywania w otaczającym ją świecie materialnym i społeczno-kulturowym [Krause, 2010; Wiliński, 2010; Chrzanowska, 2015]. Rodzaje podejmowanych działań (leczniczych, terapeutycznych) są skupione podobnie przeważnie na jednostce z pominięciem rodzajów i cech środowiska, w którym żyje, wychowuje się lub kształci. Istotne znaczenie w paradygmacie biologicznym przypisuje się zarówno medycznemu aspektowi funkcjonowaniu jednostki, jak i skierowanym na nią oddziaływaniom. Do charakterystycznej dla tego paradygmatu terminologii można zaliczyć następujące określenia:

- w odniesieniu do jednostki: uszkodzenie, upośledzenie, deficyt, defekt, defektologia, ograniczenie, dysfunkcja, zaburzenie, choroba, naruszenie sprawności, upośledzenie, odchylenie rozwojowe jednostki, indywidualne potrzeby i możliwości ucznia;

${ }^{1}$ Pod pojęciem paradygmatu rozumiem pewien dający się wyodrębnić „styl myślowy” [Fleck, 1986: 71], składający się z „zestawu założeń ontologicznych” [Śliwerski, 2009: 29], przekładający się na „ogólnie akceptowany stopień uzgodnień w środowisku” [Krause, 2010: 22], pozwalający na dokonywanie spójnej teoretycznie interpretacji, analizy i oceny wyników badań naukowych [por. Pilch, 2005: 36]. 
- w odniesieniu do postępowania wobec jednostki: diagnoza, terapia, korekcja, kompensacja, rehabilitacja, usprawnianie jednostki, indywidualne potrzeby i możliwości rozwojowe i edukacyjne, indywidualny program edukacyjno-terapeutyczny.

Przeważającą cechą paradygmatu humanistycznego jest natomiast postrzeganie każdej niepowtarzalnej osoby ludzkiej jako pozostającej w złożonych relacjach społecznych, kulturowych, językowych, zmiennych w czasie, historycznie i aksjologicznie uwarunkowanych. Osoba z niepełnosprawnością postrzegana przez pryzmat tego paradygmatu uzyskuje autonomię i możliwość decydowania o sobie, swoim życiu, dokonywania wyborów. Zyskuje na znaczeniu jej poczucie szczęścia i ogólny dobrostan, wieloaspektowe, wielowymiarowe i wielokontekstowe postrzeganie społecznej rzeczywistości [Krause, 2010]. W świetle humanistycznego paradygmatu $\mathrm{w}$ rozpoznawaniu potrzeb osoby $\mathrm{z}$ niepełnosprawnością istotne znaczenie przypisuje się czynnikom kontekstowym: środowiskowym, kulturowym, ekonomicznym itp., podejmując próbę identyfikacji barier i szans, jakie niosą dla rozwoju i możliwego dobrostanu danej osoby. Do terminologii charakterystycznej dla paradygmatu humanistycznego należałoby zatem zaliczyć takie określenia, jak:

- w odniesieniu do jednostki: interakcja między osobistymi możliwościami jednostki i kontekstem, w którym uczy się, wypoczywa, pracuje; indywidualne cechy funkcjonowania, niepełnosprawności i zdrowia; samorzecznictwo i samostanowienie; autorstwo własnego życia;

- w odniesieniu do postępowania wobec jednostki: rozpoznanie, wspieranie, wspomaganie, wzmacnianie jednostki w środowisku, współpraca, zindywidualizowane wsparcie.

Na podstawie uważnego i wielokrotnego odczytania treści wybranych aktów prawnych wyodrębniłam w nich łącznie 157 jednostek analizy. Stanowiły je ciągi wyrazów logicznie powiązanych w wypowiedź prawniczą zawartą w różnorodnych jednostkach redakcyjnych tekstu prawniczego, takich jak artykuły, paragrafy, ustępy lub punkty (przy czym jako osobne wypowiedzenia nie zostały wyodrębnione punkty oznaczane literami oraz tirety), dotyczące cech procesu wychowania i kształcenia dzieci lub uczniów ze specjalnymi potrzebami edukacyjnymi. Wśród 157 jednostek analizy większość - 100 jednostek (64\% ogółu jednostek analizowanych) - stanowiły wypowiedzenia zgodne z paradygmatem biologicznym; pozostałe - 57 jednostek analizy ( $36 \%$ ogółu wypowiedzeń) - stanowiły wypowiedzenia odpowiadające humanistycznemu rozumieniu procesu kształcenia uczniów ze specjalnymi potrzebami edukacyjnymi. Szczegółowy rozkład ilościowy wypowiedzeń przyporządkowanych do paradygmatów biologicznego i humanistycznego przedstawia tabela 1 . 
Tabela 1

Ilościowy rozkład wypowiedzeń dotyczących uczniów ze specjalnymi potrzebami edukacyjnymi w analizowanych aktach oficjalnego dyskursu pedagogicznego przyporządkowanych do przeciwstawnych paradygmatów (biologicznego lub humanistycznego)

\begin{tabular}{|c|c|c|c|c|c|c|}
\hline \multirow[t]{2}{*}{ Lp. } & \multirow[t]{2}{*}{ Akt prawny } & \multicolumn{2}{|c|}{$\begin{array}{l}\text { Wypowiedzenia } \\
\text { odpowiadające pa- } \\
\text { radygmatowi biolo- } \\
\text { gicznemu }\end{array}$} & \multicolumn{2}{|c|}{$\begin{array}{c}\text { Wypowiedzenia } \\
\text { odpowiadające para- } \\
\text { dygmatowi humani- } \\
\text { stycznemu }\end{array}$} & \multirow{2}{*}{$\begin{array}{c}\text { Ogółem } \\
\text { liczba } \\
\text { analizo- } \\
\text { wanych } \\
\text { wypo- } \\
\text { wiedzeń } \\
\mathrm{n}\end{array}$} \\
\hline & & $\mathbf{n}$ & $\%$ & $\mathbf{n}$ & $\%$ & \\
\hline 1. & $\begin{array}{l}\text { Ustawa z dnia } 7 \text { września } \\
1991 \text { r. o systemie oświaty }\end{array}$ & 15 & 83,00 & 3 & 17,00 & 18 \\
\hline 2. & $\begin{array}{l}\text { Ustawa z dnia } 14 \text { grudnia } \\
2016 \text { r. Prawo oświatowe }\end{array}$ & 10 & 71,00 & 4 & 29,00 & 14 \\
\hline 3. & $\begin{array}{l}\text { Rozporządzenie MEN z dnia } \\
9 \text { sierpnia } 2017 \text { r. w sprawie } \\
\text { warunków organizowania } \\
\text { kształcenia... }\end{array}$ & 10 & 53,00 & 9 & 47,00 & 19 \\
\hline 4. & $\begin{array}{l}\text { Rozporządzenie MEN z dnia } \\
10 \text { czerwca } 2015 \text { r. w sprawie } \\
\text { szczegółowych warunków } \\
\text { i sposobu oceniania... }\end{array}$ & 4 & 80,00 & 1 & 20,00 & 5 \\
\hline 5. & $\begin{array}{l}\text { Rozporządzenie MEN z dnia } \\
30 \text { kwietnia } 2013 \text { r. z późn. } \\
\text { zm. w sprawie zasad udzie- } \\
\text { lania i organizacji pomocy } \\
\text { psychologiczno-pedagogicz- } \\
\text { nej... }\end{array}$ & 41 & 71,00 & 17 & 29,00 & 58 \\
\hline 6. & $\begin{array}{l}\text { Rozporządzenie MEN z dnia } \\
1 \text { lutego } 2013 \text { r. w sprawie } \\
\text { szczegółowych zasad działa- } \\
\text { nia publicznych poradni psy- } \\
\text { chologiczno-pedagogicznych }\end{array}$ & 10 & 48,00 & 11 & 52,00 & 21 \\
\hline 7. & $\begin{array}{l}\text { Rozporządzenie MEN z dnia } \\
24 \text { sierpnia } 2017 \mathrm{r} \text {. w sprawie } \\
\text { organizowania wczesnego } \\
\text { wspomagania rozwoju dzieci }\end{array}$ & 6 & 35,00 & 11 & 65,00 & 17 \\
\hline 8. & $\begin{array}{l}\text { Rozporządzenie MEN z dnia } \\
9 \text { sierpnia } 2017 \text { r. w sprawie } \\
\text { indywidualnego obowiązko- } \\
\text { wego rocznego przygotowania } \\
\text { przedszkolnego... }\end{array}$ & 4 & 80,00 & 1 & 20,00 & 5 \\
\hline 9. & $\begin{array}{l}\text { Ogółem wypowiedzeń danego } \\
\text { typu }\end{array}$ & 100 & 64,00 & 57 & 36,00 & 157 \\
\hline
\end{tabular}

Źródło: badania własne. 
W wyniku zestawienia otrzymanych danych można dostrzec, że przewagę analizowanych wypowiedzeń dotyczących procesu kształcenia uczniów ze specjalnymi potrzebami edukacyjnymi w wybranych aktach oficjalnego dyskursu pedagogicznego stanowią wypowiedzenia zgodne z biologicznym paradygmatem postrzegania osób z utrudnieniami w rozwoju i uczeniu się - jest ich ponad 2/3 ogółu analizowanych wypowiedzeń (100 wypowiedzeń na 157 - 64\%).

Największa liczba wypowiedzeń odnoszących się do procesu kształcenia uczniów ze specjalnymi potrzebami edukacyjnymi znajduje się w Rozporządzeniu MEN w sprawie zasad udzielania i organizacji pomocy psychologiczno-pedagogicznej... - jest to 58 z ogółu 157 wypowiedzeń. Aż 41 spośród nich (71\%) nosi cechy paradygmatu biologicznego. W przywołanym rozporządzeniu najczęściej można zatem przeczytać o ,indywidualnych" potrzebach i możliwościach rozwojowych i edukacyjnych ucznia (nie zaś np. ucznia, jego rodziców i nauczycieli), jak też o poszczególnych kategoriach specjalnych potrzeb edukacyjnych (12 grup), co świadczy o klasyfikowaniu uczniów, a także o przywiązywaniu większej wagi nie do charakteru posiadanych przez nich potrzeb (np. wydłużonego czasu pracy, korzystania z technicznych środków komunikacji itp.), ale rodzaju przydzielonej im etykiety (niepełnosprawnego, niedostosowanego lub zagrożonego niedostosowaniem społecznym, z zaburzeniami zachowania lub emocji, szczególnie uzdolnionego itd.). O procesie rozpoznawania potrzeb uczniów mówi się przeważnie, stosując określenia o silnym rodowodzie medycznym, takie jak „diagnoza” czy „postdiagnoza”, wynik tych procesów określając rozpoznaniem „trudności w funkcjonowaniu w szkole lub oddziale wynikających z zaburzeń rozwojowych lub ze stanu zdrowia”, „zaburzeń i odchyleń rozwojowych”, a proces wspierania ucznia sprowadzając do „terapii”, „korekcji”, „,kompensacji” itp.

Podobnie wyższą zgodność z biologicznym paradygmatem postrzegania osób z trudnościami w rozwoju i uczeniu się ujawnia większość pozostałych analizowanych przeze mnie aktów prawnych. Niestety, należą do tej grupy dwa podstawowe akty o mocy ustaw: Ustawa z dnia 7 września 1991 r. o systemie oświaty oraz Ustawa z dnia 14 grudnia 2016 r. Prawo oświatowe. Podobnie zwraca się w nich uwagę przede wszystkim na ,indywidualne cechy rozwojowe i edukacyjne ucznia” ze specjalnymi potrzebami edukacyjnymi, ,specyfikę jego funkcjonowania percepcyjno-motorycznego i poznawczego", jego "możliwości psychofizyczne” jako podstawowy wyznacznik kształtowania praktyki edukacyjnej. W wyniku zaplanowanych działań, przede wszystkim „wielospecjalistycznej oceny funkcjonowania ucznia” czy ,indywidualnego programu edukacyjno-terapeutycznego", oczekuje się przede wszystkim ,poprawy funkcjonowania ucznia” czy „wzmocnienia jego uczestnictwa w życiu przedszkolnym lub szkolnym”. Znacznie rzadziej w kontekście kształcenia uczniów ze specjalnymi potrzebami edukacyjnymi można przeczytać o możliwości np. zwolnienia ucznia z określonych rodzajów zajęć edukacyjnych „uwzględniając specyfikę danych zajęć edukacyjnych oraz celowość realizacji przez ucznia niektórych treści nauczania", o możliwości przystąpienia do egzaminu ósmoklasisty „w warunkach odpowiednich” do potrzeb ucznia określonych w orzeczeniu, opinii lub w zaświadczeniu lekarskim, 
o „zindywidualizowanym” procesie kształcenia czy „odpowiedniej organizacji zajęć dydaktycznych".

Podobnie w Rozporządzeniu MEN z dnia 9 sierpnia 2017 r. w sprawie warunków organizowania kształcenia..., Rozporządzeniu MEN z dnia 10 czerwca 2015 r. w sprawie szczegółowych warunków i sposobu oceniania..., Rozporządzeniu MEN z dnia 9 sierpnia 2017 r. w sprawie indywidualnego obowiązkowego rocznego przygotowania przedszkolnego... znacznie częściej można przeczytać o wadze ,indywidualnych potrzeb rozwojowych i edukacyjnych oraz możliwościach psychofizycznych ucznia” niż o stosowaniu „odpowiednich metod i form pracy z uczniem” czy o tym, że „,należy uwzględnić wpływ zaburzeń lub dysfunkcji ucznia na jego zachowanie". Częściej czytamy o udzielaniu pomocy uczniowi aniżeli o podejmowaniu działań wspierających wszystkich uczestników procesu edukacyjnego (rodziców, nauczycieli, wychowawców grup wychowawczych, nauczycieli specjalistów) przez osoby i instytucje działające w szkole i poza nią (zwłaszcza poradnie psychologiczno-pedagogiczne). Jednak chyba najrzadziej można dostrzec w tekście analizowanych wypowiedzeń dotyczących uczniów ze specjalnymi potrzebami edukacyjnymi ujawniające dociekanie przyczyn ewentualnych rozbieżności pomiędzy możliwościami ucznia a oczekiwaniami wobec niego, wskazywanie na konieczność namysłu nad „zakresem i charakterem wsparcia ze strony nauczycieli, specjalistów, asystentów lub pomocy nauczyciela", uświadamianie praw rodziców i uczniów w procesie kształcenia oraz w toku planowania, prowadzenia i oceniania procesu wspierania rozwoju i uczenia się dziecka. Tylko w jednym miejscu wspomina się o prawach rodziców i uczniów do poszanowania ich dóbr osobistych i konieczności nieujawniania spraw ich dotyczących. Znamienne jest, że równie rzadko wśród czynników, które mogą mieć znaczenie zarówno w przezwyciężaniu trudności, jak i w ich indukowaniu, wymienia się np. „czynniki środowiskowe wpływające na funkcjonowanie ucznia” czy „bariery i ograniczenia utrudniające funkcjonowanie ucznia”. Nie często też podkreśla się konieczność współpracy wszystkich uczestników procesu edukacyjnego, ,monitorowania efektów działań podejmowanych w celu poprawy funkcjonowania ucznia oraz planowania dalszych”, ,wspierania nauczycieli” czy „wspomagania szkoły lub placówki” także przez zewnętrzne podmioty.

Wśród analizowanych aktów prawnych są jednak dwa, w których niewielką przewagę zdobywa paradygmat humanistyczny. W Rozporządzeniu MEN z dnia 1 lutego $2013 \mathrm{r}$. w sprawie szczegółowych zasad działania publicznych poradni psychologiczno-pedagogicznych i w Rozporządzeniu MEN z dnia 24 sierpnia 2017 r. w sprawie organizowania wczesnego wspomagania rozwoju dzieci można przeczytać, że poradnie mają za zadanie udzielać pomocy „dzieciom, od momentu urodzenia, i młodzieży [...] rodzicom i nauczycielom [...], a także wspomagają przedszkola, szkoły i placówki w zakresie realizacji zadań dydaktycznych, wychowawczych i opiekuńczych” z uwzględnieniem ,,potrzeb lokalnej społeczności”; pełnić funkcję doradczą $\mathrm{w}$,określeniu niezbędnych do nauki warunków, sprzętu specjalistycznego i środków dydaktycznych, w tym wykorzystujących technologie informacyjno-komunikacyjne”, podejmować działania w celu ,eliminowania barier i ograniczeń w środowisku utrudniających jego [dziecka - A.O.] funkcjonowanie", 
w tym nieść pomoc „w przystosowaniu warunków w środowisku domowym do potrzeb dziecka oraz w pozyskaniu i wykorzystaniu w pracy z dzieckiem odpowiednich środków dydaktycznych i niezbędnego sprzętu".

Reasumując, w wyniku przeprowadzonej analizy terminów i określeń dotyczących dzieci i młodzieży z trudnościami w rozwoju i uczeniu się uczęszczających do placówek ogólnodostępnych lub integracyjnych znajdujących się w analizowanych wypowiedzeniach pochodzących $\mathrm{z}$ wybranych aktów prawa oświatowego mogę sformułować następujące wnioski:

- Dzieciom i młodzieży odbiegającym od ogólnie przyjętej „normy” rozwojowej i edukacyjnej (niepełnosprawnym, niedostosowanym społecznie lub zagrożonym niedostosowaniem społecznym oraz z jeszcze inaczej uwarunkowanymi specjalnymi potrzebami edukacyjnymi) udzielana jest pomoc psychologiczno-pedagogiczna (paradygmat biologiczny).

- Pomoc psychologiczno-pedagogiczna udzielana jest również rodzicom i nauczycielom uczniów (paradygmat humanistyczny).

- Pomoc udzielana jest we współpracy (paradygmat humanistyczny).

- Pomoc udzielana jest na wniosek rodziców, uczniów, nauczycieli... (paradygmat humanistyczny).

- Rodzice ucznia i pełnoletni uczeń mogą być obecni na posiedzeniu nauczycieli i specjalistów opracowujących indywidualny program edukacyjno-terapeutyczny i mają prawo otrzymać kopię tego programu (paradygmat humanistyczny).

- Dzieci i młodzież, którym udzielana jest pomoc, to uczniowie: „niepełnosprawni”, „,niedostosowani społecznie”, „zagrożeni niedostosowaniem społecznym”, „przewlekle chorzy”, ,z zaburzeniami”, „,z niepowodzeniami”, „z trudnościami”, a nawet „ze specyficznymi trudnościami”, „zaniedbani środowiskowo" (paradygmat biologiczny).

- Sposób rozpoznawania indywidualnych potrzeb i możliwości ucznia to diagnoza (paradygmat biologiczny).

- Pomoc psychologiczno-pedagogiczna udzielana uczniom może przybierać formy: „klas terapeutycznych”, „zajęć o charakterze terapeutycznym”, „korekcyjno-kompensacyjnych” (paradygmat biologiczny).

- Działania podejmowane są wobec uczniów, których trudności wynikają z ich niepełnosprawności, z ich zaburzeń, z ich trudności, z ich chorób (paradygmat biologiczny).

- Działania podejmowane wobec uczniów mają miejsce w przedszkolu, szkole lub placówce (paradygmat biologiczny).

- Kontekst rozwoju, uczenia się, spędzania czasu wolnego prawie w ogóle nie jest brany pod uwagę zarówno w procesie diagnozy, jak i terapii, wyjątek stanowią uczniowie, których trudności mogą mieć związek z sytuacją środowiskową (zaniedbanie, sytuacje traumatyczne lub kryzysowe, zagrożenie niedostosowaniem lub niedostosowanie społeczne) (paradygmat biologiczny).

- Kompetencje osób dorosłych zajmujących się uczniami są rozdzielone „Zwykłymi” uczniami zajmuje się „,zwykły” nauczyciel, „specjalnymi” 
uczniami - nauczyciel specjalista (nauczyciel współorganizujący proces kształcenia) (paradygmat biologiczny).

- Pomocy udziela się według odgórnie przygotowanego planu działania (w odniesieniu do uczniów posiadających orzeczenie o potrzebie kształcenia specjalnego - indywidualnego programu edukacyjno-terapeutycznego) opracowanego DLA ucznia BEZ jego aktywnego udziału (paradygmat biologiczny).

Wśród przedstawionych wniosków (z uwagi na ograniczenie długości tekstu nie mogą to być wszystkie wnioski, jakie można sformułować w wyniku analizy treści przepisów prawa oświatowego) wyraźnie widać, że większość z nich $(61 \%$ ogółu analizowanych wypowiedzeń) odpowiada biologicznemu, jak zauważa Amadeusz Krause [2010]: „ustępującemu” paradygmatowi biologicznemu. Wciąż bowiem znacznie silniej w analizowanych dokumentach akcentowane są braki, a nie tzw. mocne strony uczniów, znacznie więcej miejsca poświęca się temu, co zrobić, gdy coś/ktoś nie spełnia odgórnie wyznaczonych kryteriów, nie zaś temu, jak elastyczne powinno być stanowisko i działania szkoły, aby jak największa liczba jej uczniów mogła odnieść indywidualny sukces, choćby nieporównywalny z osiągnięciami innych dzieci i młodzieży. Jawna jest w nich segregacja uczniów na kategorie (w zmienionym Rozporządzeniu MEN z dnia 30 kwietnia 2013 r. wymienia się ich aż 12), którym nadaje się „,szczególną̧ rangę, w ukryty sposób dyskryminując tym samym pozostałych uczniów, np. w sytuacji oceniania, gdy trudności występujące u dziecka „specjalnego” bierze się pod uwagę, a u dziecka „Zwykłego” już nie lub nie tak chętnie. W ten sposób dochodzi bowiem do fragmentacji uczniów podobnej do fragmentacji osób niepełnosprawnych, o której pisze Mateusz Wiliński [2010].

Należy jednak przyznać, że widoczne są także pierwsze ,jaskółki” rekontekstualizacji cech humanistycznego paradygmatu w analizowanych aktach prawa oświatowego. Fakt, że w ogóle zauważa się i prawnie sankcjonuje jakąkolwiek współpracę szkoły z innymi środowiskami, może bowiem być jeszcze wciąż kruchym, ale już możliwym fundamentem wielośrodowiskowych działań. Czego zatem jeszcze brakuje aktom prawa oświatowego, aby lepiej odpowiadały współczesnym kierunkom przemian paradygmatycznych w pedagogice i wyłaniającemu się humanistycznemu paradygmatowi? Sądzę, że przede wszystkim brak jest zapisów dotyczących podejmowania określonych działań w bezpośrednim środowisku społeczno-edukacyjnym ucznia i z pełnym respektowaniem jego podmiotowości. Poznawanie indywidualnych możliwości i potrzeb rozwojowych i edukacyjnych ucznia powinno iść bowiem w parze z poznawaniem kontekstu tych procesów (jakimi zasobami dysponuje uczeń, jakimi jego rodzina, jakimi szkoła) oraz z uwzględnianiem ich dynamiki (zwłaszcza przez odejście od sztywnego ustalenia w czasie, kiedy może być wydana kolejna opinia lub orzeczenie). Do aktów prawa regulujących codzienną praktykę szkolną i funkcjonowanie w niej uczniów z trudnościami rozwojowymi i edukacyjnymi powinno się również systematycznie wprowadzać terminologię przenoszącą uwagę z diagnozy na poznawanie, $z$ terapii na wspomaganie, wspieranie, $z$ indywidualnego programu 
edukacyjno-terapeutycznego na program zindywidualizowanego wsparcia (wsparcie psychospołeczne, techniczne, uniwersalny design).

Jak, mam nadzieję, udało mi się wykazać, współczesny oficjalny dyskurs pedagogiczny zawiera cechy przeciwstawnych paradygmatów (skądinąd charakterystycznych dla pograniczności transformacyjnej pedagogii), a znacznie większa część przepisów zawartych w analizowanych aktach prawa oświatowego odpowiada paradygmatowi biologicznemu, tradycjonalizmowi i adaptacyjnej racjonalności. Po takiej konstatacji nie sposób zatem postawić choćby dwóch pytań: Czy jest możliwe prowadzenie skutecznej polityki edukacyjnej na podstawie aktów prawnych odzwierciedlających jednocześnie założenia konkurujących (aby nie powiedzieć: sprzecznych) paradygmatów pedagogicznych? Czy tak skonstruowany przekaz oficjalnego dyskursu pedagogicznego może przeciwdziałać, czy raczej utrwala istniejące stereotypy postrzegania uczniów z trudnościami rozwojowymi i edukacyjnymi? Pojęcia mogą być zarówno bezpośrednim następstwem funkcjonowania danego paradygmatu, jak i odzwierciedlać jego zmiany. Opór wobec zmian terminologii może oznaczać uporczywe trwanie poprzedniego paradygmatu lub jego elementów w świadomości społecznej i środowisku naukowym [Krause, 2009: 9-24]. Czy zatem cechy przeciwstawnych pedagogicznych paradygmatów uwidaczniające się w wybranych aktach prawa oświatowego raczej odzwierciedlają zachodzące w tym zakresie zmiany, czy też są dowodem na uporczywe trwanie sposobów myślenia zakorzenionego jeszcze w tradycji XIX-wiecznej? Odpowiedzi na te pytania poszukajmy we własnym języku i komunikacji codziennej oraz we własnej praktyce pedagogicznej.

\section{Bibliografia}

Baron-Wiaterek M. (2010), Konstytucyjnoprawne aspekty zabezpieczenia praw społecznych osób niepetnosprawnych [w:] L. Frąckiewicz, W. Koczur (red.), Zabezpieczenie społeczne osób niepetnosprawnych, Wydawnictwo Akademii Ekonomicznej, Katowice.

Bernstein B. (2000), Pedagogy, Symbolic Control, and Identity, Rowman \& Littlefield Publishers, Inc., Boston.

Bernstein B. (2003), Class, Codes and Control, vol. 4: The Structuring of Pedagogic Discourse, Routledge, London.

Bińczycka J. (red.) (2000), Humaniści o prawach dziecka, Oficyna Wydawnicza Impuls, Kraków.

Bińczycka J. (2002), Podmiotowość a prawa dziecka [w:] M. Nowicka-Kozioł (red.), Prawo głosu i różnicy a podmiotowość, Wydawnictwo Akademii Pedagogiki Specjalnej, Warszawa.

Bińczycka J. (2005), O kilku niespetnionych prawach dziecka [w:] J. Bińczycka, B. Smolińska-Theiss (red.), Wymiary dzieciństwa. Problemy dziecka i dzieciństwa w zmieniajacym się społeczeństwie, Oficyna Wydawnicza Impuls, Kraków.

Bobeł B. (2003), Integracyjne oddziały przedszkolne szansa integracji społecznej dzieci niepetnosprawnych [w:] S. Włoch (red.), Edukacja przedszkolna w teorii i praktyce, Wydawnictwo Uniwersytetu Opolskiego, Opole. 
Buchnat M. (2014), Kompetencje i oczekiwania nauczyciela do pracy z dzieckiem ze specjalnymi potrzebami edukacyjnymi w nowej szkolnej rzeczywistości, „Studia Edukacyjne” 31, 177-193.

Chrzanowska I. (2010), Problemy edukacji dzieci i młodzieży z niepetnosprawnością: regionalna specyfika czy ogólnopolska tendencja, Oficyna Wydawnicza Impuls, Kraków.

Chrzanowska I. (2015), Pedagogika specjalna. Od tradycji do współczesności, Oficyna Wydawnicza Impuls, Kraków.

Ciechanowski J. i in. (oprac.), Prawo do edukacji dzieci o specjalnych potrzebach edukacyjnych. Raport z monitoringu, Helsińska Fundacja Praw Człowieka, Warszawa.

Czyż E. (2002), Prawa dziecka, Helsińska Fundacja Praw Człowieka, Warszawa.

Dębniak A. (2001), Osoby niepetnosprawne w świetle unormowań Konstytucji RP z 1997 roku [w:] T. Jasudowicz (red.), Polska wobec europejskich standardów praw człowieka, Wydawnictwo „Dom Organizatora” TNOiK, Toruń.

Domagała-Zyśk E. (2012), Relacje rówieśnicze uczniów z niespecyficznymi trudnościami w nauce [w:] E. Domagała-Zyśk (red.), Uczeń ze specjalnymi potrzebami edukacyjnymi w środowisku rówieśniczym, Wydawnictwo KUL, Lublin.

Dreesen P., Judkowiak J. (2012), Bierni na Wschodzie, ponoszacy zbiorowa winę i oczywiście obecni w Europie - krytyka niemieckich i polskich podręczników do historii w oparciu o kontrastywna lingwistyke dyskursu, „Tekst i Dyskurs - Text und Diskurs”, 5.

Dudzińska A. (2009), Wszystko jasne. Dostępność i jakość edukacji dla uczniów niepetnosprawnych $w$ Warszawie, Stowarzyszenie Pomocy Dzieciom z Ukrytymi Niepełnosprawnościami im. Hansa Aspergera „Nie-Grzeczne Dzieci”, Warszawa.

Dudzińska A. (2012), Prawo dziecka niepetnosprawnego do nauki w szkole ogólnodostępnejwskazówkidla rodzicówiopiekunów, https://www.academia.edu/29597315/Prawo_dziecka_ niepe $\%$ C5\%82nosprawnego_do_nauki_w_szkole_og\%C3\%B3lnodost $\%$ C4\%99pnej_-_ wskaz\%C3\%B3wki_dla_rodzic\%C3\%B3w_i_opiekun\%C3\%B3w [dostęp: 22.05.2017].

Fleck L. (1986), Powstanie i rozwój faktu naukowego. Wprowadzenie do nauki o stylu myślowym i kolektywie myślowym, tłum. M. Tuszkiewicz, Wydawnictwo Lubelskie, Lublin.

Gajdzica Z. (2001), Nauczyciel edukacji wczesnoszkolnej w zreformowanej szkole powszechnej jako organizator procesu kształcenia dziecka upośledzonego umysłowo w stopniu lekkim [w:] Z. Palak (red.), Pedagogika specjalna $w$ reformowanym ustroju edukacyjnym, UMCS, Lublin.

Gajdzica Z. (2003). Wybrane uwarunkowania procesu kształcenia ucznia z lekkim upośledzeniem umysłowym w niższych klasach szkoły podstawowej ogólnodostępnej [w:] Z. Kazanowski, D. Osik-Chudowska (red.), Integracja osób niepetnosprawnych w edukacji i interakcjach społecznych, UMCS, Lublin.

Gajdzica Z. (red.) (2007), Rozwój i funkcjonowanie osób niepełnosprawnych. Konteksty edukacyjne i prawne, Oficyna Wydawnicza Impuls, Kraków.

Gajdzica Z. (2011), Opinie nauczycieli szkół ogólnodostępnych na temat edukacji włączającej uczniów z lekkim upośledzeniem umysłowym w kontekście toczacej się reformy kształcenia specjalnego [w:] Z. Gajdzica (red.), Uczeń z niepełnosprawnościa w szkole ogólnodostępnej, Oficyna Wydawnicza Humanitas, Sosnowiec.

Głębowski J. (2009), Problemy rzecznictwa i reprezentacji środowisk osób niepełnosprawnych w Unii Europejskiej - wybrane aspekty prawne [w:] D. Podgórska-Jachnik (red.), 
Problemy orzecznictwa i reprezentacji osób niepetnosprawnych, Wydawnictwo WSP/ EGP, Łódź.

Jachimczak B. (2008), Gotowość nauczycieli szkół ogólnodostępnych do pracy z uczniem o specjalnych potrzebach edukacyjnych [w:] I. Chrzanowska, B. Jachimczak (red.), Miejsce Innego we wspótczesnych naukach o wychowaniu - wyzwania praktyki, Wydawnictwo Satori, Łódź.

Jachimczak B. (2009), Rodzice dzieci niepetnosprawnych jako ich rzecznicy $w$ rozwiazywaniu problemów rozwojowych i edukacyjnych [w:] D. Podgórska-Jachnik (red.), Problemy orzecznictwa i reprezentacji osób niepetnosprawnych, Wydawnictwo WSP/EGP, Łódź.

Jagiełło K., Sałacińska A., Kamasa V. (2014), Rodzina w podręcznikach do nauki języka fińskiego oraz polskiego dla obcokrajowców. Krytyczna Analiza Dyskursu, „Tekst i Dyskurs - Text und Diskurs", 7.

Jankowska M. (2012), Prawa osób niepetnosprawnych $w$ międzynarodowych aktach, prawnych, „Niepełnosprawność - Zagadnienia, Problemy, Rozwiązania”, 2, https://www. pfron.org.pl/kn/poprzednie-numery/68, Prawa-osob-niepelnosprawnych-w-miedzynarodowych-aktach-prawnych-The-rights-of-di.html [dostęp: 22.05.2017].

Kamiński J. (2006), Osoby z niepetnosprawnościa intelektualna w prawie Unii Europejskiej, Sprawni w Prawie, z. 6, Polskie Stowarzyszenie na Rzecz Osób z Upośledzeniem Umysłowym, Warszawa.

Kawczyńska-Butrym Z. (red.) (2002), Wybrane aspekty funkcjonowania pomocy społecznej na rzecz osób niepetnosprawnych intelektualnie, „Auxilium Sociale. Wsparcie Społeczne", 3-4.

Kościelska M. (2000), Sytuacja dzieci niepetnosprawnych w Polsce w 10 lat po uchwaleniu Konwencji Praw Dziecka [w:] J. Bińczycka (red.), Humaniści o prawach dziecka, Oficyna Wydawnicza Impuls, Kraków.

Krause A. (2010), Współczesne paradygmaty pedagogiki specjalnej, Oficyna Wydawnicza Impuls, Kraków.

Kubicki P. (2012), Równy dostęp do edukacji osób z niepetnosprawnościami [w:] [A. Błaszczak (red.)], Najważniejsze wyzwania po ratyfikacji przez Polskę Konwencji ONZ o Prawach Osób Niepetnosprawnych, Biuletyn Rzecznika Praw Obywatelskich. Źródła, nr 10, Biuro Rzecznika Praw Obywatelskich, Warszawa.

Kukla D., Duda W., Czerw-Bajer M. (2011), Osoby niepetnosprawne w systemie edukacji i poradnictwa zawodowego, Difin, Warszawa.

Kummant M. (oprac.) (2008), Raport. Tendencje w kształceniu integracyjnym w Polsce w latach 2003-2008, Pracownia Wspomagania Rozwoju i Integracji CMPP-P, Warszawa.

Kurowski K. (2009), Regulacje Unii Europejskiej dotyczace osób niepetnosprawnych, „Biuletyn Euroniepełnosprawni”, 1(12).

Kurowski K. (2010), Ewolucja regulacji prawnych Organizacji Narodów Zjednoczonych w zakresie problematyki osób niepetnosprawnych [w:] D. Podgórska-Jachnik (red.), Problemy rzecznictwa i reprezentacji osób niepelnosprawnych, t. 2: Ruch na rzecz lepszej przyszłości osób niepetnosprawnych, Wydawnictwo WSP/EGP, Łódź.

Lacan J. (1996), Funkcja i pole mówienia i mowy w psychoanalizie, tłum. B. Gorczyca, W. Grajewski, Wydawnictwo KR, Warszawa.

Maciarz A. (1992), Uczniowie niepetnosprawni w szkole powszechnej, WSiP, Warszawa. 
Martin-Jones M., de Mejia A.M., Hornberger N.H. (2008), Encyclopedia of Language and Education, $2^{\text {nd }}$ ed., vol. 3: Discourse and Education, Springer \& Business Media LLC, New York.

Mikołajczyk-Lerman G. (2012), Sytuacja dzieci niepełnosprawnych w świetle praw dziecka [w:] W. Warzywoda-Kruszyńska (red.), Bieda dzieci, zaniedbanie, wykluczenie społeczne, Wydawnictwo Uniwersytetu Łódzkiego, Łódź.

Mikołajczyk-Lerman G. (2013), Między wykluczeniem a integracją realizacja praw dziecka niepetnosprawnego i jego rodziny. Analiza socjologiczna, Wydawnictwo Uniwersytetu Łódzkiego, Łódź.

Najwyższa Izba Kontroli (2012), Kształcenie uczniów z niepełnosprawnościami o specjalnych potrzebach edukacyjnych. Informacja o wynikach kontroli, Warszawa.

Ochonczenko H. (2005), Idea równych szans osób niepetnosprawnych w wybranych dokumentach prawnych [w:] Cz. Kosakowski, A. Krause (red.), Normalizacja środowisk życia osób niepetnosprawnych, Wydawnictwo UWM, Olsztyn.

Olechowska A. (2006), Dostep do edukacji dzieci o specjalnych potrzebach [w:] T. Szlendak (red.), Mate dziecko w Polsce. Raport o sytuacji edukacji elementarnej, Fundacja Rozwoju Dzieci im. J.A. Komeńskiego, Warszawa.

Olechowska A. (2016), Uczeń ze specjalnymi potrzebami edukacyjnymi w oficjalnym dyskursie pedagogicznym [w:] I. Adamek, J. Bałachowicz (red. nauk.), Pomiędzy dwiema edukacjami. Dziecko/uczeń wobec czasu zmiany, Wyższa Szkoła Pedagogiczna w Łodzi, Łódź.

Osiecka J. (1998), Ksztatcenie osób niepetnosprawnych w Polsce - stan obecny i perspektywy, Biuro Studiów i Ekspertyz, Informacja nr 635, http://biurose.sejm.gov.pl/teksty/i-635. htm [dostęp: 22.05.2017].

Perlin M.L. (2002), Prawa osób niepełnosprawnych intelektualnie i chorych psychicznie [w:] J. Sikorska (red.), Społeczne problemy osób niepetnosprawnych, Wydawnictwo IFiS PAN, Warszawa.

Pilch T. (red.) (2005), Encyklopedia pedagogiczna XXI wieku, t. 4, Wydawnictwo Edukacyjne Żak, Warszawa.

Przybylski S. (2003), Refleksje nad barierami występujacymi przy wdrażaniu integracji osób niepetnosprawnych w Polsce [w:] Z. Kazanowski, D. Osik-Chudowolska (red.), Integracja osób niepetnosprawnych w edukacji i interakcjach społecznych, Wydawnictwo UMCS, Lublin.

Przybysz P. (1997), Prawa człowieka a prawa niepetnosprawnych, Warszawa Biuro RPO, http://piotr_marek_przybysz.republika.pl/teksty/disabled.pdf [dostęp: 22.05.2017].

Rutkowiak J., Krause A. (2009), Obszary społecznej marginalizacji-niepełnosprawność, Olsztyńska Szkoła Wyższa im. J. Rusieckiego, Olsztyn.

Rzecznik Praw Obywatelskich (2012a), Najważniejsze wyzwania po ratyfikacji przez Polskę Konwencji ONZ o Prawach Osób Niepetnosprawnych, „Biuletyn Rzecznika Praw Obywatelskich", 10.

Rzecznik Praw Obywatelskich (2012b), Równe szanse $w$ dostępie do edukacji osób z niepetnosprawnościami. Analiza i zalecenia, „Biuletyn Rzecznika Praw Obywatelskich”, 7.

Rzecznik Praw Obywatelskich (2013), Wystapienie do Ministra Edukacji Narodowej w sprawie równego dostęu do edukacji osób z niepetnosprawnościami, RPO/604478/08/I/106.3 RZ, https://www.portaloswiatowy.pl/wazne-wydarzenia-dla-szkol-i-przedszkoli/rpo-rowne-szanse-dla-uczniow-z-niepelnosprawnosciami-5015.html [dostęp: 22.05.2017]. 
Sowa J. (2006), Prawne podstawy procesu rehabilitacji edukacyjnej [w:] I. Marczykowska, E. Markowska-Gos, A. Solak, W. Walc (red.), Prawa dziecka. Wybrane aspekty, Wydawnictwo Uniwersytetu Rzeszowskiego, Rzeszów.

Szeroczyńska M. (2004), Prawa dziecka niepetnosprawnego w Unii Europejskiej [w:] Prawa dziecka po przystapieniu do Unii Europejskiej, Rzecznik Praw Dziecka, Warszawa.

Szumski G. (2006), Integracyjne kształcenie niepetnosprawnych. Sens i granice zmiany edukacyjnej, Wydawnictwo Naukowe PWN, Warszawa.

Szymańczak J. (1999), Konwencja o prawach dziecka ONZ. Uwagi o realizacji konwencji przez Rzeczpospolita Polska, Informacja 684, http://biurose.sejm.gov.pl/teksty/i-684.htm [dostęp: 22.05.2017].

Śliwerski B. (2009), Współczesna myśl pedagogiczna. Znaczenia, klasyfikacje, badania, Oficyna Wydawnicza Impuls, Kraków.

Van Dijk T. (2001), Dyskurs jako struktura i proces, Wydawnictwo Naukowe PWN, Warszawa.

Wachowiak A. (1992), Błędy nauczycieli szkót masowych w postepowaniu z dziećmi niepetnosprawnymi [w:] A. Hulek, B. Grochmal-Bach (red.), Uczeń niepetnosprawny w szkole masowej, Wydawnictwo WSP, Kraków.

Warzywoda-Kruszyńska W. (2011), Niepetnosprawność w dzieciństwie - zagrożenie bieda $i$ wykluczeniem społecznym [w:] W. Warzywoda-Kruszyńska, G. Mikołajczyk-Lerman (red.), Uczeń i student niepetnosprawny - warunki życia i nauki, Wydawnictwo Biblioteka, Łódź.

Warzywoda-Kruszyńska W., Holets N. (2011), Prawne aspekty edukacji osób niepetnosprawnych [w:] W. Warzywoda-Kruszyńska, G. Mikołajczyk-Lerman (red.), Uczeń i student niepetnosprawny - warunki życia i nauki, Wydawnictwo Biblioteka, Łódź.

Wiącek G. (2008), Efektywna integracja szkolna. Systemowy model uwarunkowań powodzenia w kształceniu integracyjnym, Towarzystwo Naukowe KUL, Lublin.

Wiliński M. (2010), Modele niepetnosprawności - indywidualny - funkcjonalny - społeczny [w:] A. Brzezińska, R. Kaczan, K. Smoczyńska (red.), Diagnoza potrzeb i modele pomocy dla osób z ograniczeniami sprawności, Wydawnictwo Naukowe Scholar, Warszawa.

Woźniak Z. (2008), Niepetnosprawność i niepetnosprawni w polityce społecznej-społeczny kontekst medycznego problemu, Wydawnictwo Szkoły Wyższej Psychologii Społecznej „Academica”, Warszawa.

Zabłocki K.J. (1999), Dziecko niepetnosprawne jego rodzina i edukacja, Wydawnictwo Akademickie Żak, Warszawa.

Zima M., Sałagan P. (2008), Niepetnosprawne dzieci [w:] Polska droga do Konwencji o prawach osób niepetnosprawnych ONZ, Fundacja Instytut Rozwoju Regionalnego, Kraków. 